\title{
Food Solutions New England: Racial equity, food justice, and food system transformation
}

\author{
Joanne D. Burke a* \\ University of New Hampshire
}

Karen A. Spiller ${ }^{b}$

KAS Consulting and University of New Hampshire

\begin{abstract}
Submitted June 24, 2015 / Published online September 17, 2015
Citation: Burke, J. D., \& Spiller, K. A. (2015). Food Solutions New England: Racial equity, food justice and food system transformation. Journal of Agriculture, Food Systems, and Community Development, 5(4), 165-171. http://dx.doi.org/10.5304/jafscd.2015.054.027
\end{abstract}

Copyright (C) 2015 by New Leaf Associates, Inc.

\begin{abstract}
When originally conceived, the efforts of Food Solutions New England (FSNE) were centered on discovering the potential and possibility of working together as a six-state entity. Our first New England summit was convened in 2011. We considered the benefits of working together regionally, explored the possibilities of promoting greater food justice, and embraced the merits of expanding food production via the concept of a

a * Corresponding author: Joanne D. Burke, PhD, RD, LD., Thomas W. Haas Professor of Sustainable Food Systems, University of New Hampshire (UNH) Sustainability Institute; co-chair of Food Solutions New England, Racial Equity and Food Justice Working Group; and director of the UNH Dietetic Internship in the UNH Nutrition Program. She can be contacted at 129 Main Kendall Hall, Kendall Hall; Durham, New Hampshire 03824 USA; +1-603-862-1456; joanne.burke@unh.edu

${ }^{\mathrm{b}}$ Karen A. Spiller, KAS Consulting, Principal, and University of New Hampshire, Sustainability Institute, co-chair of Food Solutions New England, Racial Equity and Food Justice Working Group. She can be contacted at KAS Consulting; P.O. Box 52476; Boston, Massachusetts 02205 USA.
\end{abstract}

New England Food Vision. By 2012 we had adopted the collective impact model as a way to organize our work. In 2013, during this first year of breakout sessions we identified "racial equity and food justice" as non-negotiable, explicit attributes that should inform all food system work. We continue to learn and demonstrate a commitment to promoting greater racial equity and food justice through a variety of network and community strategies. Select examples from FSNE's efforts are provided as evidence of the power of collective impact and regional collaboration. As states and regions come together to challenge the status quo, share strategies, and align policies and practices designed to address food system inequities, we are emboldened, knowing that our collective commitment and actions will have implications that extend well beyond the food system.

\section{Keywords}

food systems, racial equity, food justice, New England Food Vision, collective impact, food insecurity, racial disparity, sustainability 
This food system works for some, but fails too many of us. Yet, we have a glimpse of the possibility of a just and healthy food system. To get there, we must use a critical race lens to diagnose what's wrong with the current system, assess entry points for change, and determine ways that we can work together to build a better system for all of us. (Gaincatarino \& Noor, 2014, p. 4)

\section{Current Realities}

During the past 20 years, there has been increasing interest in understanding food system viability and sustainability. Efforts often have focused on food production and the potential economic and environmental benefits to farmers, consumers, and local and regional food enterprises. In this issue of the Journal of Agriculture, Food Systems, and Community Development, we have the opportunity to explore efforts and commitments that explicitly focus on the role of racial equity and food justice as integral components of food system transformation. As we challenge the status quo, share strategies, and explore policies and practices designed to promote greater racial equity and food justice, we realize this is indeed a journey in which we are all learning. We are know that this work is essential and its positive impact will extend well beyond the grocery cart.

With input from a regional steering committee, in 2011 the University of New Hampshire Sustainability Institute launched an inaugural "Better Together" summit, designed to learn more about each state's food system work and to leverage commitment to building a more just, democratic, and sustainable food system. Another key theme addressed at our first conference was structural racism. Cathrine Sneed, founder of The Garden Project in San Francisco, served as a keynote speaker, and attendees viewed the FSNE Voices from the Field video. ${ }^{1}$ Efforts at this first summit to build alignment around common goals and explore regional food production and fisheries capacity have led to the emergence of Food Solutions New England (FSNE), a highly collaborative food

${ }^{1}$ See the Voices from the Field video at https://www.youtube.com/watch?v=igb2VHAtx5M system "learning action network" (FSNE, 2015a); the 2014 release of the report $A$ New England Food $V$ ision (Donahue et al., 2014); and extensive connections, relationships, alignments, and learning among numerous state and regional partners. Our regional capacity to connect, envision possibilities, build relationships, and leverage resources has been enhanced by using the collective impact model proposed by Kania and Kramer (2011). As a network of individuals, partners, and organizations, we have been able to help each other in efforts designed to advance policies and practices that transform the food and fisheries system into one that works for all (Bowell et al., 2014; FSNE, 2015b). The evolution of the regional commitment to an explicit emphasis on racial equity and food justice in food system work in 2013 is indicative of our transformation as a region, and of the larger national discourse on the need for structural changes that dismantle racial inequalities and injustice across the American social, political, and economic systems.

\section{Historical Context and Implications}

The American food system has been defined by its exploitation of Native American lands, development of an agricultural trade system built on the backs of slave labor, and a lack of appreciation for farmers and farmworkers. Unfortunately, from farm to fork, to health and nutrition outcomes, food system inequality persists nearly 150 years after the end of the Civil War and over 50 years after passage of "landmark" civil rights legislation. Though the need for food unites us all, access to healthy food and the ability to fully participate in the food system is often divided along racial and ethnic lines. As we commit to designing a more equitable food future that supports a high quality of life for generations to come, we are compelled to address the pervasive systemic racial disparity operating at all levels of the food system. There is increased awareness by non-Hispanic Whites (and a lived experience by others) that White privilege and structural racism are actively and insidiously at play. According to Lawrence and Keleher (2004):

Structural racism in the U.S. is the normalization and legitimization of an array of dynamics 
-historical, cultural, institutional and interpersonal—that routinely advantage Whites while producing cumulative and chronic adverse outcomes for people of color. It is a system of hierarchy and inequity, primarily characterized by white supremacy - the preferential treatment, privilege and power for White people at the expense of Black, Latino, Asian, Pacific Islander, Native American, Arab and other racially oppressed people. (p. 1)

For instance, if you are Black or Hispanic in the United States you are less likely to own farmland (U.S. Census of Agriculture, 2012), to be able to procure healthy foods (Coleman-Jensen, Gregory, \& Singh, 2014; Coleman-Jensen, Rabbitt, Gregory, \& Singh, 2015; DeNavas-Walt \& Proctor, 2014), to have a livable wage income (Restaurant Opportunities Centers United, 2013; U.S. Bureau of Labor Statistics, 2014a, 2014b; U.S. Census Bureau, 2013), to have adequate access to money (Sommeiller \& Price, 2015), or to have health outcomes comparable to White, non-Hispanic individuals (Agency for Healthcare Research and Quality, 2014). Table 1 displays how food insecurity, poverty, and unemployment disproportionately affect Blacks, Hispanics, and Asians, compared with non-Hispanic Whites.

Indeed, many of the food system indicators of inequity are related and virtually inseparable. Under- and unemployment leads to poverty and food insecurity. Higher paying jobs often require a college education. Given the high cost of a college education, many students from Black and Hispanic families are not in a financial position to attend college, thus limiting earning and wealth accumulation opportunities. But even when employed in similar food system jobs, People of Color tend to earn less than Whites (Sommeiller \& Price, 2015). Likewise, when one lives in poverty, defined as an annual income of US $\$ 24,250$ for a family of four (Office of the Assistant Secretary for Planning and Evaluation, 2015), the ability to choose healthy food (U.S. Bureau of Labor Statistics, 2015) and to engage in preventative healthcare is severely compromised.

\section{Emerging Food System Strategies}

Often when we think about racism, we focus on individual attitudes or behaviors, which is important. Sometimes, we look at how particular institutions treat people of different races differently, which is also important. But to truly understand the root causes of racial inequity and thereby produce solutions that work for everyone, we need to take a structural race approach. That means looking at the food system through the lens of policies, institutions and people-together.

(Gaincatarino \& Noor, 2014, p. 6)

Table 1: Food Insecurity, Poverty, and Unemployment by Race and Ethnicity

\begin{tabular}{|c|c|c|c|c|c|c|c|}
\hline \multirow[b]{2}{*}{ Race and Ethnicity } & \multirow[b]{2}{*}{$\begin{array}{l}\% \text { Food } \\
\text { Secure (a) }\end{array}$} & \multicolumn{3}{|c|}{$\%$ Food Insecurity (a) } & \multirow{2}{*}{$\begin{array}{l}\text { \% of Total U.S. } \\
\text { Population } \\
\text { (b) }\end{array}$} & \multirow{2}{*}{$\begin{array}{l}\text { \% Below } \\
\text { Poverty } \\
\text { (c) }\end{array}$} & \multirow[b]{2}{*}{$\begin{array}{l}\text { \% Unemployed } \\
\text { (d and e) }\end{array}$} \\
\hline & & $\begin{array}{l}\text { \% Total Food } \\
\text { Insecurity }\end{array}$ & $\begin{array}{l}\text { \% Low Food } \\
\text { Security }\end{array}$ & $\begin{array}{c}\% \text { Very Low } \\
\text { Food Security }\end{array}$ & & & \\
\hline White, non-Hispanic & 89.4 & 10.6 & 6.0 & 4.6 & 64 & 9.6 & 5.3 \\
\hline Black, non-Hispanic & 73.9 & 26.1 & 15.9 & 10.1 & 14 & 27.2 & 11.3 \\
\hline Hispanic & 76.3 & 23.7 & 17.0 & 6.7 & 17 & 23.5 & 7.4 \\
\hline Other (a) & 88.3 & 11.7 & 6.5 & 5.2 & & & \\
\hline Asian (b) & & & & & 5 & 10.5 & 5.0 \\
\hline
\end{tabular}

a Coleman-Jensen et al., 2014: The USDA includes food security data for the Asian population in the "other" category

b U.S. Census Bureau, 2013: provides specific data for the Asian population in its demographic and poverty datasets.

c DeNavas-Walt, C. \& Proctor, 2014.

d U.S. Bureau of Labor Statistics, 2014a.

e U.S. Bureau of Labor Statistics, 2014b. 
The food system is a microcosm of larger social systems that exist nationally and globally, but is one that people interact with intimately on a daily basis. The extreme complexity of the food system, coupled with the intricacies of the social, environmental, and economic systems in which it operates, demands complex, long-term skills and strategy development to ensure that the voices and needs of all food consumers are addressed now and into the future. It is no longer sufficient to demand expansion of the Supplemental Nutrition Assistance Program (SNAP), a program that now serves nearly one in seven Americans (over 46 million Americans) who exist in poverty. In addition to securing immediate food needs, we need to interrogate why there are so many Americans who must rely to SNAP in order to provide food for themselves or their household members, and why are People of Color more apt to require SNAP assistance (Gray, 2014)? As proposed by Eric HoltGiménez (2015):

Activists across the food movement are beginning to realize that the food system cannot be changed in isolation from the larger economic system. Sure, we can tinker around the edges of the issue and do useful work in the process. However, to fully appreciate the magnitude of the challenges we face and what will be needed to bring about a new food system in harmony with people's needs and the environment, we need to understand and confront the social, economic, and political foundations that created — and maintain — the food system we seek. (p. 25)

\section{FSNE's Commitment to Addressing Racial Equity and Food Justice Explicitly in Food System Work}

As we consider selected examples of FSNE's commitment to addressing racial equity and food justice explicitly as central to its efforts, we do so in the spirit of knowing full well that we are not working or learning alone. Rather, it is the collective efforts of multiple regional and national partners, organizations, and activists who are committed to using food as a driver for greater social justice and racial equity.
During the first FSNE summit in 2011, we posed the question, "Would the New England states benefit from coming together and working on food system issues in a more collective and concerted manner?" With the recent convening of Summit Five in 2015, this six-state regional network has unequivocally answered that question in the affirmative. During our first summit, Vermont shared its newly released Farm to Plate Strategic Plan (Vermont Sustainable Jobs Fund, 2011) and offered assistance to the other states working on food system planning. Presently, all New England states either have statewide food plans or are drafting statewide plans or strategies. The initial concept call to examine New England's food production and fisheries capacity was also proposed in 2011; in Spring 2014, the report $A$ New England Food Vision was released (Donahue et al., 2014). During the three-year, highly iterative process of developing this aspirational document, which initially focused on New England's production capacity by land and by sea, the conversation and focus of the Vision expanded. Input by diverse partners, organizations, and summit attendees informed our collective thinking and consciousness. A New England Food Vision proposes that New England could produce 50 percent of New England's food needs by 2060, and nearly twothirds of its food requirements if we needed to move towards greater regional reliance. $A$ New England Food Vision calls for access to healthy food to be considered as a basic human right (Anderson, 2013; Donahue et al., 2014). As noted by Tom Kelly, in the introduction page,

This vision is bold in scope and aspiration. It reflects a point of view informed by two principles: first, food is a powerful determinant of all aspects of quality of life the world over, including New England. Second, New Englanders can and should pursue a future in which food nourishes a social, economic, and environmental landscape that supports a high quality of life for everyone, for generations to come. So this vision is all about our choices and the conversation, learning, and purposeful decision-making in which we as a region can participate. (Donahue et al., 2014, front cover) 
In March of 2015, FSNE hosted a webinar to explore how $A$ New England Food Vision could be put to work in communities and the region (Kelly, Donahue, Spiller, Bourns, Burke, \& Beal, 2015). With the UNH Sustainability Institute functioning as the backbone organization, using collective impact as a model (Kania \& Kramer, 2011), taking the time and energy to build relationships, engaging highly skilled professional facilitation staff, building collaborative and diverse teams, and having public and philanthropic support (FSNE, 2015c) has shaped us as individuals and as a regional network. FSNE now defines itself as:

A regional, collaborative network organized around a single goal: to transform the New England food system into a resilient driver of racial equity and food justice, health, sustainable farming and fishing, and thriving communities. (FSNE, 2015d)

In addition to an expanded goal statement and the release of the $A$ New England Food Vision report, and in service of increased racial equity in food system transformation, we continue to seek ways to increase diverse active participation. During this past year, we have launched an Ambassador program in the three most populated and racially diverse New England states: Connecticut, Massachusetts, and Rhode Island. Our three ambassadors have reached out to diverse audiences, and have engaged with and brought in additional people of color and organizations committed to comprehensively addressing the role of race and food justice in the food system. When funding permits, we anticipate our pilot Ambassador program will be expanded into the remaining New England States (Maine, New Hampshire, and Vermont).

As we expand the voices at the food system transformation table, our food system conversations are more rich and diverse. For instance, at summit number five in June 2015 individuals directly engaged in food service work were invited as a new delegation to the summit. Our participants were far more diverse by age and race than other summits. We remain committed to building diversity into our work and extended networks, as do our existing network partners.

In addition to our broad-based community and regional engagement, we have made a commitment to our food system planning teams and regional team partners to provide opportunities to help build our own internal capacity to thoughtfully address the subject of racial equity and food justice. Our regional facilitator, Curtis Ogden, from the Interaction Institute for Social Change, has worked with us for over three years and has extensive expertise in food system and racial equity work (Ogden, 2015). Our planning team meetings have included training sessions with national experts as well as with members of our extended New England network. FSNE also has started to develop working groups, including the Racial Equity and Food Justice working group. A major accomplishment of the working group this year was to expand upon the work of Moore and Irving to develop guidelines and resources for our first annual 21-Day Racial Equity Habit Building Challenge, launched in March 2015 (Moore \& Irving [adapted by Spiller, Ogden, \& Burke], 2015).

As FSNE continues on this journey, we will lift up our voices and use our collective power, of all races, to increase racial equity and food justice as a model for successful replicable system change. Racism and injustice are not unique to the food system. But the daily requirements for nourishment, the enormous work force that is involved directly and indirectly in the food system, and the extensive environmental and economic implications of food system injustice combine to provide compelling multi-sector opportunities through which transformational change can be realized.

Now our struggle is for genuine equality, which means economic equality. For we know now, that it isn't enough to integrate lunch counters. What does it profit a man to be able to eat at an integrated lunch counter if he doesn't have enough money to buy a hamburger? (King, 1968) 


\section{References}

Agency for Healthcare Research and Quality. (2014). National healthcare quality and disparities report (Pub. No. 15-0007). Rockville, Maryland: U.S. Department of Health and Human Services, AHRQ. Retrieved from http://www.ahrq.gov/research/ findings/nhqrdr/nhqdr14/index.html

Anderson, M. D. (2013). Beyond food security to realizing food rights in the US. Journal of Rural Studies, 29, 113-122.

http://dx.doi.org/10.1016/j.jrurstud.2012.09.004

Bowell, B., Coffin, C., Courchesne, C., Frignoca, I., Greene, M., Iarrapino, A.,...Ruhf, K. (2014). New England food policy: Building a sustainable food system. Washington, D.C.: American Farmland Trust, Conservation Law Foundation, Northeast Sustainable Agriculture Working Group. Retrieved from http://www.clf.org/wp-content/uploads/ 2014/03/1.New England Food Policy FULL.pdf

Coleman-Jensen, A., Gregory, C., \& Singh A. (2014). Household food security in the United States in 2013 (Report No. ERR-173). Washington, D.C.: U.S. Department of Agriculture, Economic Research Service. Retrieved from http://www.ers.usda.gov/ media/1565415/err173.pdf

Coleman-Jensen, A., Rabbitt, M., Gregory, C., \& Singh, A. (2015). Household food security in the United States in 2014 ( Report No. ERR-194). Washington, D.C.: U.S. Department of Agriculture, Economic Research and Service. Retrieved from http://www.ers.usda.gov/publications/erreconomic-research-report/err194.aspx

DeNavas-Walt, C., \& Proctor, B. D. (2014). Income and poverty in the United States: 2013 (Current Population Reports, P60-249). Washington, D.C.: U.S. Department of Commerce, U.S. Census Bureau. Retrieved from http://www.census.gov/ content/dam/Census/library/publications/2014/ demo/p60-249.pdf

Donahue, B., Burke, J., Anderson, M., Beal, A., Kelly, T., Lapping, M.,...Berlin, L. (2014). A New England food vision. Durham: University of New Hampshire, Sustainability Institute, FSNE. Retrieved from http://www.foodsolutionsne.org/sites/default/ files/LowResNEFV 0.pdf

Food Solutions New England. (2015a). Who we are/what we believe. Durham, New Hampshire: FSNE. Retrieved from http://www.foodsolutionsne.org/ what-we-believe
Food Solutions New England. (2015b). Six states, one region. Durham, New Hampshire: FSNE. Retrieved from http:/ / www.foodsolutionsne.org/six-statesone-region/regional-alignment

Food Solutions New England. (2015c). Who we are/ how we work. Durham, New Hampshire: FSNE. Retrieved from http://www.foodsolutionsne.org/ who-we-are/how-we-work

Food Solutions New England. (2015d). Transforming New England's food system together. Durham, New Hampshire: FSNE. Retrieved from http://www.foodsolutionsne.org/

Gaincatarino, A., \& Noor, S. (2014). Building the case for racial equity in the food system. New York: Center for Social Inclusion. Retrieved from http://www.centerforsocialinclusion.org/buildingthe-case-for-racial-equity-in-the-food-system/

Gray, F. K. (2014). Characteristics of Supplemental Nutrition Assistance Program households: Fiscal year 2013 (Report SNAP-14-CHAR). Alexandria, Virginia: USDA, Food and Nutrition Service, Office of Policy Support. Retrieved from http://www.fns.usda.gov/sites/default/files/ops/ Characteristics2013.pdf

Holt-Giménez, E. (2015). Racism and capitalism: Dual challenges for the food movement. Journal of Agriculture, Food Systems, and Community Development, 5(2), 23-25. http://dx.doi.org/10.5304/jafscd.2015.052.014

Kania, J., \& Kramer, M. (2011). Collective impact. Stanford Social Innovation Review, 9(1), 36-41. Retrieved from http://www.ssireview.org/articles/ entry/collective impact

Kelly, T., Donahue, B., Spiller, K., Bourns, C., Burke, J., \& Beal, A. (2015, March 17). Putting a New England food vision to work [Webinar]. Durham: University of New Hampshire, Sustainability Institute. Retrieved from https://www.youtube.com/watch?v=xLM krnwDcdE\&feature $=$ youtu.be

King, M. L., Jr. (1968). Speech in Memphis, Tennessee. Retrieved from http://www.dailykos.com/story/ 2013/01/21/1180824/-Martin-Luther-King-JrOur-struggle-is-for-genuine-equality-which-meanseconomic-equality

Lawrence, K., \& Keleher, T. (2004). Chronic disparity: Strong and pervasive evidence of racial inequalities: Poverty outcomes: Structural racism. Race and Public Policy Conference, 2004. Retrieved from http://www.intergroupresources.com/rc/ Definitions $\% 20$ of $\% 20$ Racism.pdf 
Moore, E., \& Irving, D. (Adapted by Spiller, K., Ogden, C., \& Burke, J.). (2015). The 21-day racial equity habit building challenge. Durham, New Hampshire: FSNE. Retrieved from http://www.foodsolutionsne.org/ get-involved/21-day-racial-equity-habit-buildingchallenge

Office of the Assistant Secretary for Planning and Evaluation. (2015). U.S. federal poverty guidelines used to determine financial eligibility for certain federal programs. Washington, D.C.: U.S. Department of Health and Human Services. Retrieved from http://aspe.hhs.gov/poverty/15poverty.cfm

Ogden, C. (2015). Senior associate. Boston, Massachusetts: Interaction Institute for Social Change. Retrieved from http://interactioninstitute.org/people/curtisogden/

Restaurant Opportunities Centers United. (2013). Realizing the dream: How the minimum wage impacts racial equity in the restaurant industry and in America. New York: Author. Retrieved from http://rocunited.org/wp-content/uploads/2014/ 02/report_realizing-the-dream.pdf

Sommeiller, E., \& Price, M. (2015). The increasingly unequal states of America: Income inequality by state, 1917 to 2012. Washington, D.C.: Economic Analysis and Research Network. Retrieved from http://s3.epi. org/files/2014/IncreasinglyUnequalStatesof America1917to2012.pdf

U.S. Bureau of Labor Statistics. (2014a). Household data annual averages. Table 5: Employment status of the civilian non-institutional population by sex, age, and race 2014.
Washington, D.C.: U.S. Department of Labor, U.S. Bureau of Labor Statistics. Retrieved from http://www.bls.gov/cps/cpsaat05.pdf

U.S. Bureau of Labor Statistics. (2014b). Household data annual averages. Table 6: Employment status of the Hispanic or Latino population by sex, age, and detailed ethnic group. Washington, D.C.: U.S. Department of Labor, U.S. Bureau of Labor Statistics. Retrieved from http://www.bls.gov/cps/cpsaat06.pdf

U.S. Bureau of Labor Statistics. (2015). Consumer expenditures in 2013 (Report No. 1053). Washington, D.C.: U.S. Department of Labor, U.S. Bureau of Labor Statistics. Retrieved from http://www.bls.gov/cex/csxann13.pdf

U.S. Census Bureau. (2013). USA QuickFacts. Washington, D.C.: U.S. Census Bureau, U.S. Department of Commerce. Retrieved from http://quickfacts.census.gov/qfd/states/ $\underline{00000 . h t m l}$

U.S. Census of Agriculture. (2012). Race/ethnicity/gender profile. Washington, D.C.: U.S. Department of Agriculture, National Agricultural Statistics Service. Retrieved from http://www.agcensus.usda.gov/ Publications/2012/Online Resources/Race, Ethnicity and Gender Profiles/cpd99000.pdf

Vermont Sustainable Jobs Fund. (2011). Farm to plate strategic plan. Montpelier, Vermont: Vermont Sustainable Jobs Fund, Vermont Farm to Plate Network. Retrieved from http://www.vtfarmtoplate.com/plan/ 